\title{
PERANCANGAN SISTEM PAKAR DALAM MENDIAGNOSA PENYAKIT PADA BALITA
}

\author{
Anggya N.D. Soetarmono, S.Kom.*
}

\begin{abstract}
ABSTRAK
Banyaknya kejadian yang mengakibatkan kematian terhadap balita (anak yang baru berumur kurang dari 1 tahun) pada akhir abab XIX di Amerika Serikat, dikarenakan terinfeksi oleh penyakit. Perkembangan sistem pakar dalam menangani segala bidang ilmu telah berkembang secara pesat, dimana sistem pakar tersebut telah dapat menirukan penalaran seorang pakar dalam menguasai bidang ilmu tersebut. Dengan menerapkan sistem pakar dalam mengetahui gejala penyakit yang diderita oleh kebanyakan balita, akan sangat membantu dalam mengurangi jumlah kematian pada balita.
\end{abstract}

Kata Kunci: Balita, Penyakit, Sistem Pakar.

\section{PENDAHULUAN}

Sistem pakar sudah banyak dikembangkan baik untuk kepentingan penelitian maupun kepentingan bisnis dari berbagai bidang ilmu seperti ekonomi, keuangan, teknologi dan kedokteran. Sistem pakar dalam diagnosis kesehatan telah dikembangkan pada pertengahan tahun 1970 di Stanford University. Sistem tersebut diberi nama MYCIN dan digunakan untuk melakukan diagnosis dan terapi terhadap penyakit ${ }^{1}$ meningitis dan ${ }^{2}$ infeksi bakteremia.

\subsection{Latar Belakang}

Penyakit yang tidak kalah penting adalah penyakit pada balita. Ilmu kesehatan anak (pediatri) memperhatikan gangguan pada setiap sistem atau fungsi yang mungkin mempunyai dampak pada kesehatan atau pertumbuhan dan perkembangan anak yang teratur. Tanggung jawab ahli pediatri, selain dalam persoalan fisik semata mata, adalah untuk memastikan agar semua anak mendapat kesempatan untuk mencapai kesanggupan alamiah mereka sepenuhnya. Dalam tugas sebagai penjaga kemajuan fisik, mental dan emosional anak dari konsepsi dewasa, ahli pediatri ada dibarisan terdepan dari perhatian sosial untuk anak-anak dan keluarga mereka.

Pediatri dibedakan sebagai suatu keahlian medik khusus kira-kira satu abad yang lalu terhadap bartambahnya pengetahuan bahwa masalah anak-anak berbeda dari masalah orang dewasa dan bahwa masalah-masalah itu dan reaksi anak terhadapnya berbeda-beda menurut umur. Fokus dan bidang pediatri telah mengalami perubahan secara terus menerus.

\footnotetext{
* Staf Pengajar Program Studi S1-Sistem Informasi IKADO

${ }^{1}$ Meningitis adalah bakteri yang disebabkan olch bakteri Intluenzae yang dapat ditemukan didalam tcnggorokkan (yang mengakihatkan infeksi pernafasan).

${ }^{2}$ Bakteremia adalah bakteri dalam darah yang disebabkan oleh bakteri Escherichia Coli yang kebanyakan penderita suhu badan melebihi 38,9 derajat Celsius.
} 
Di Amerika Serikat, pada akhir abad XIX dari setiap seribu anak lahir hidup dapat diharapkan bahwa 200 orang anak akan meninggal sebelum berumur 1 tahun karena keadaan seperti ${ }^{3}$ diare, ${ }^{4}$ pneumonia, ${ }^{5}$ difteri dan lain-lain. Seperti banyak negara yang sedang berkembang, kesehatan anak-anak di Amerika Serikat ketinggalan jauh dibelakang yang seharusnya jika cara-cara dan kemauan untuk menerapkan pengetahuan mutakhir dapat dipraktekkan, masalah medis anak-anak sering berhubungan erat dengan masalah kesehatan jiwa dan kesehatan sosial. Anak-anak dengan resiko paling besar terdapat dalam perbandingan yang tidak seimbang diantara kelompok-kelompok etnik minoritas. Ahli pediatric mempunyai tanggung jawab untuk memusatkan perhatiannya kepada masalah seperti ini.

\subsection{Perumusan Masalah}

Dari apa yang telah diuraikan pada pendahuluan maka perumusan masalah dari penelitian ini dapat dijabarkan sebagai berikut:

1. Bagaimana komputer dapat menelusuri penyakit dengan meng-input gejala penyakit pada balita.

2. Bagaimana komputer dapat membantu memberikan informasi yang baik untuk mengatasi penyakit pada balita.

\subsection{Tujuan dan Manfaat Penelitian}

Dari penelitian, dapat disimpulkan terdapat beberapa tujuan dan manfaat:

1. Agar setiap keluarga mendapatkan pertolongan pertama dalam menangani panyakit pada balita.

2. Agar setiap keluarga dapat pertolongan pertama mengatasi dan mencegah penyakit pada balita sebelum mengantri ke dokter.

3. Agar setiap keluarga dapat meringankan beban mereka mengantri ke dokter.

\subsection{Hipotesis}

Secara umum pengetahuan didalam sistem pakar dari para pakar pada bidang yang spesifik, sehingga sistem pakar cenderung menjadi seorang spesialis yang berfokus pada sejumlah masalah yang sempit dan terbatas. Seperti juga manusia, pengetahuan dalam sistem pakar diperoleh secara teori dan praktek (pengalaman). Melalui sistem pakar, sistem komputer melakukan ekstraksi informasi tambahan dari user dengan memberikan sejumlah pertanyaan yang terkait dengan permasalahan selama konsultasi.

Pemakaian sistem pakar :

- Oleh orang awam yang bukan pakar untuk meningkatkan kemampuan mereka dalam memecahkan masalah.

- Oleh pakar sebagai asisten yang berpengetahuan.

- Untuk memperbanyak atau menyebarkan sumber pengetahuan yang semakin langka.

\footnotetext{
${ }^{3}$ Diare adalah penigkatan frekuensi, keenceran dan volume tinja (keenceran tinja).

${ }^{4}$ Pneumonia adalah infeksi terhadap paru-paru yang disebabkan oleh virus dan bakteri.

${ }^{5}$ Difteri adalah penyakit menular akut yang dapat ditularkan melalui tetesan air liur, batuk, bersin atau bicara.
} 


\section{LANDASAN TEORI}

Ada bebserapa definisi konsep sistem pakar dan sejarah sistem pakar yang perlu diketahui dan akan dijelaskan dalam mempelajari sistem pakar dan membangun suatu sistem kepakaran.

\subsection{Sejarah}

Sistem pakar mulai dikembangkan pada pertengahan tahun 1960-an Artificial Intelligence Corporation. Periode penelitian artificial intelligence ini didominasi oleh suatu keyakinan bahwa nalar yang digabungkan dengan komputer canggih akan menghasilkan prestasi pakar atau bahkan manusia super.

Suatu usaha kearah ini adalah General Purpose Problem-Solver (GPS). GPS yang berupa sebuah prosedur yang dikembangkan oleh Allen Newell, John Cliff Shaw, dan Herbert Alexander Simon dari Logic Theorist merupaka sebuah percobaan untuk menciptakan mesin cerdas. GPS sendiri merupakan sebuah predecessor menuju sistem pakar.

Pada pertengahan tahun 1970-an, beberapa sistem pakar mulai muncul. Sebuah pengetahuan kunci yang dipelajari saat itu adalah kekuatan dari sistem pakar berasal dari pengetahuan spesifik yang dimilikinya, bukan dari formalismeformalisme khusus dan pola penarikan kesimpulan yang digunakannya. Awal 1980an, teknologi sistem pakar yang mula-mula dibatasi oleh suasana akademis mulai muncul sebagai aplikasi komersil, khususnya XCON, XSEL (dikembangkan dari R-1 pada Digital Equipment Corp.) dan CATS-1 (dikembangkan oleh General Electric).

\subsection{Pengertian Sistem Pakar}

Sistem pakar adalah program berbasis pengetahuan yang menyediakan penyelesain berkualitas pakar untuk masalah-masalah dalam sebuah bidang yang spesifik. Sistem pakar adalah salah satu sub bidang artificial intelligence, mendampingi Neural Language Processing (NLP) atau Pengolahan Bahasa Alami, dan Robotics atau Robotika.

\subsection{Sifat Pada Sistem Pakar}

Adapun beberapa ciri - ciri umum dari sistem pakar :

- Terbatas pada bidang yang spesifik.

- Dapat memberikan penalaran untuk data-data yang tidak lengkap atau tidak pasti.

- Dapat mengemukakan rangkaian alasan yang diberikannya dengan cara yang dapat dipahami.

- Berdasarkan pada rule atau kaidah tertentu.

- Dirancang untuk dapat dikembangkan secara bertahap.

- Outputnya bersifat nasihat atau anjuran.

- Output tergantung dari dialog dengan user.

- Knowledge base dan inference engine terpisah.

Umumnya, kepakaran seorang manusia terdiri dari aktivitas berikut ini :

- Mengenali dan merumuskan masalah.

- Menyelesaikan masalah secara cepat dan layak.

- Menjelaskan solusinya.

- Belajar dari pengalaman.

- Me-restrukturisasi pengetahuan. 


\subsection{Arsitektur Sistem Pakar}

Sebagai sebuah sistem yang selalu memiliki sejumlah komponen yang harus berinteraksi untuk mencapai tujuan, komponen utama yang harus ada dalam sebuah sistem pakar adalah:

- Knowledge Base (basis pengetahuan).

- Inference Engine (mesin penarik kesimpulan).

- Explanation Subsystem (subsistem penjelas output).

- User-Interface (penghubung ke pemakai).

Sedangkan komponen-komponen berikut tidaklah mutlak dalam sebuah sistem pakar yaitu :

- Knowledge Base Editor

- Data pada kasus yang spesifik

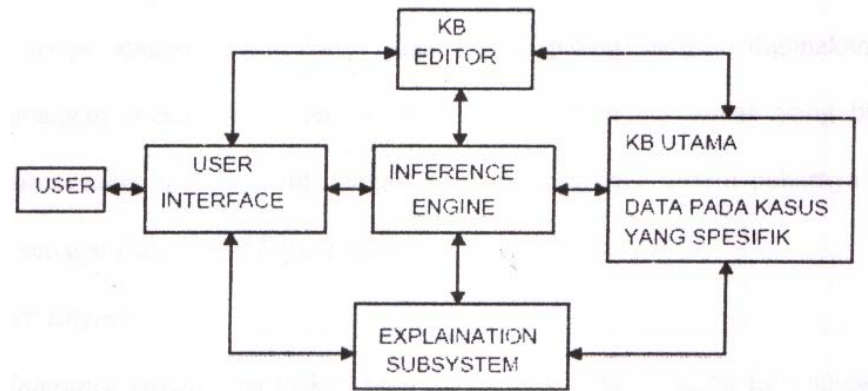

\section{Gambar Arsitektur Dalam Membangun Sistem Pakar}

1. Knowledge Base

Knowledge base atau basis pengetahuan merupakan representasi pengetahuan dari seorang pakar yang diperlukan untuk memahami, memformulasikan dan memecahkan masalah. Terdiri dari dua elemen dasar, yaitu:

- Fakta yang berupa informasi tentang situasi permasalahan, teori dari area permasalahan atau informasi tentang objek.

- Spesial heuristic yang merupakan informasi tentang cara bagaimana membangkitkan fakta baru dari fakta yang sudah diketahui. Dalam sistem pakar berbasis rule, bagain ini berupa rules.

Knowledge base adalah jantung sebuah sistem pakar. Bagian ini adalah totalitas keahlian pakar yang telah didasarikan dan diformat ke dalam external memory komputer. Sampai saat ini terdapat berbagai cara representasikan knowledge yang telah dikenal, misalnya penyajian yang berorientasi obyek, jaringan semantik, frame, script ataupun production rules. Yang paling banyak digunakan pada pengembangan sistem pakar dengan shell (paket program) adalah yang berbasis production rules, biasa disebut dengan rule saja sehingga sistem pakarnya sering disebut sebagai Rule-based Expert System.

2. Inference Engine

Inference engine merupakan otak dari sistem pakar, bagian ini mengandung mekanisme fungsi berpikir dan pola-pola penalaran sistem yang digunakan oleh seorang pakar. Mekanisme ini akan menganalisa suatu masalah tertentu dan kemudian mencari jawaban atau kesimpulan yang terbaik. Dari fakta-fakta yang diperoleh selama proses tanya-jawab dengan user, serta rule-rule yang tersimpan di knowledge base, inference engine dapat menarik suatu kesimpulan dan memberikan rekomendasi atau saran yang diharapkan oleh user. 


\section{Explanation Subsystem}

Bagian yang harus siap memberikan penjelasan saat mana user perlu mengetahui apakah alasan yang diberikannya merupakan sebuah solusi. Bagian ini secara konkrit membedakan sebuah sistem pakar dengan sistem aplikasi yang biasa, karena pada pemrograman konvensional tidaklah biasa sebuah sistem menyediakan informasi tambahan mengapa atau mana sebuah solusi diperoleh. Bagian ini mempunyai kemampuan untuk menelusuri konklusi dan menerangkan tingkah laku sistem pakar dengan menjawab pertanyaan-pertanyaan seperti:

- Mengapa pertanyaan tersebut diajukan oleh sistem pakar?

- Bagaimana atau darimana konklusi tersebut diperoleh?

- Mengapa alternative tersebut ditolak?

Pada sistem pakar berbasis rule, biasanya penjelasan ini dilakukan dengan cara memperlihatkan rule-rule yang digunakan. Fasilitas ini penting untuk menambahkan rasa percaya user pada hasil output program sistem pakar yang digunakannya.

4. User Interface

Merupakan bagian dari sistem pakar yang berfungsi sebagai pengendali input output. User interface melayani user selama proses konsultasi mulai dari tanya - jawab untuk mendapatkan fakta - fakta yang dibutuhkan oleh inference engine sampai menampilkan output yang merupakan kesimpulan atau rekomendasi yang dihasilkan oleh inference engine.

5. Knowledge-based Editor

Bagian yang digunakan untuk menghapus atau memperbaiki basis pengetahuan. Bagian ini tidaklah mutlak, karena mayoritas sistem pakar berbasis pengetahuan dalam format text-file, sehingga bagian ini dapat digantikan dengan berbagai word processor yang tersedia. Namun demikian bila sistem pakar dituntut untuk memiliki kemampuan machine learnig dari pengalaman konsultasinya, bagian ini menjadi sangat vital.

6. Data pada kasus yang spesifik

Bagian ini hanya diperlukan saat mana data yang telah dimiliki pemakai file database atau spreadsheet, diperlukan sebagai referensi untuk menarik kesimpulan.

\section{METODE PENELITIAN}

Setelah membahas konsep sistem pakar pada penjelasan sebelumnya, maka selanjutnya adalah membangun atau mendesain suatu sistem pakar dalam mendiagnosa penyakit pada balita. Hasil wawancara dengan seorang dokter yang pernah menangani penyakit pada bayi, beliau mengatakan bahwa sebenarnya penyakit pada bayi secara umum tidak banyak, misalnya alergi, batuk, diare, demam berdarah, kejang atau malaria. Bila bayi misalnya menderita panas maka, dilihat panasnya berapa derajat celcius dan diberi obat penurun panas (parasetamol) dan bila bayi tersebut panas badannya tidak menurun maka, segera dibawa kedokter. Dalam mendiagnosa penyakit pada balita, maka kita akan melihat dari status umur balita yang akan didiagnosa antara lain prasekolah (umur 1 sampai 4 tahun). Setelah kita melihat dari status umur pada balita yang akan didiagnosa, maka spesifikasi status umur balita yang akan digunakan dalam mendiagnosa penyakit pada balita untuk penelitian ini adalah status umur balita prasekolah (umur 1 sampai 4 tahun). 
Dalam mendiagnosa penyakit pada balita yang dilakukan terlebih dahulu adalah melakukan Anamnesis (wawancara atau tanya jawab) yang biasanya dilakukan oleh para dokter untuk mendapatkan informasi kondisi penyakit pada balita sebelum dilakukan pengobatan atau penanganan lebih lanjut. Dalam melakukan anamnesis ada beberapa hal yang pasti ditanyakan untuk mengetahui kondisi penyakit balita antara lain mengenai gejala penyakit yang dialami oleh balita, kondisi temperatur atau suhu badan balita, setelah itu baru ditentukan penyakit apa yang dialami oleh pasien atau balita tersebut.

\subsection{Menargetkan Pengambilan Keputusan}

Sistem pakar yang dirancang akan mendukung decision making dengan memberikan rekomendasi tentang penanganan penyakit yang akan diberikan kepada seorang pasien. Menunjukkan factor-faktor kritis yang diperlukan untuk menghasilkan sebuah rekomendasi :

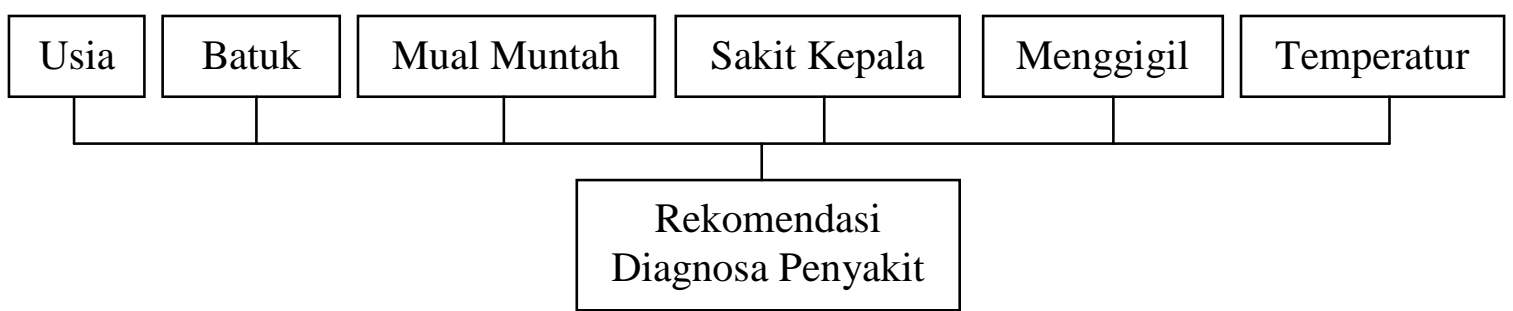

Gambar Arsitektur Pengambilan Keputusan (Block Diagram)

\subsection{Membentuk Diagram Ketergantungan}

Sasaran pengambilan keputusan yang akan dibuat prototypenya ditransformasikan kedalam sebuah diagram ketergantungan (dependency diagram). Diagram ketergantungan menunjukkan semua pertanyaan input yang diperlukan, jumlah rule dan rule set yang harus dibuat, dan semua alternatif jawaban yang disediakan (values). Termasuk ke dalam values adalah jenis rekomendasi akhir yang disarankan sebagai output prototype ini.

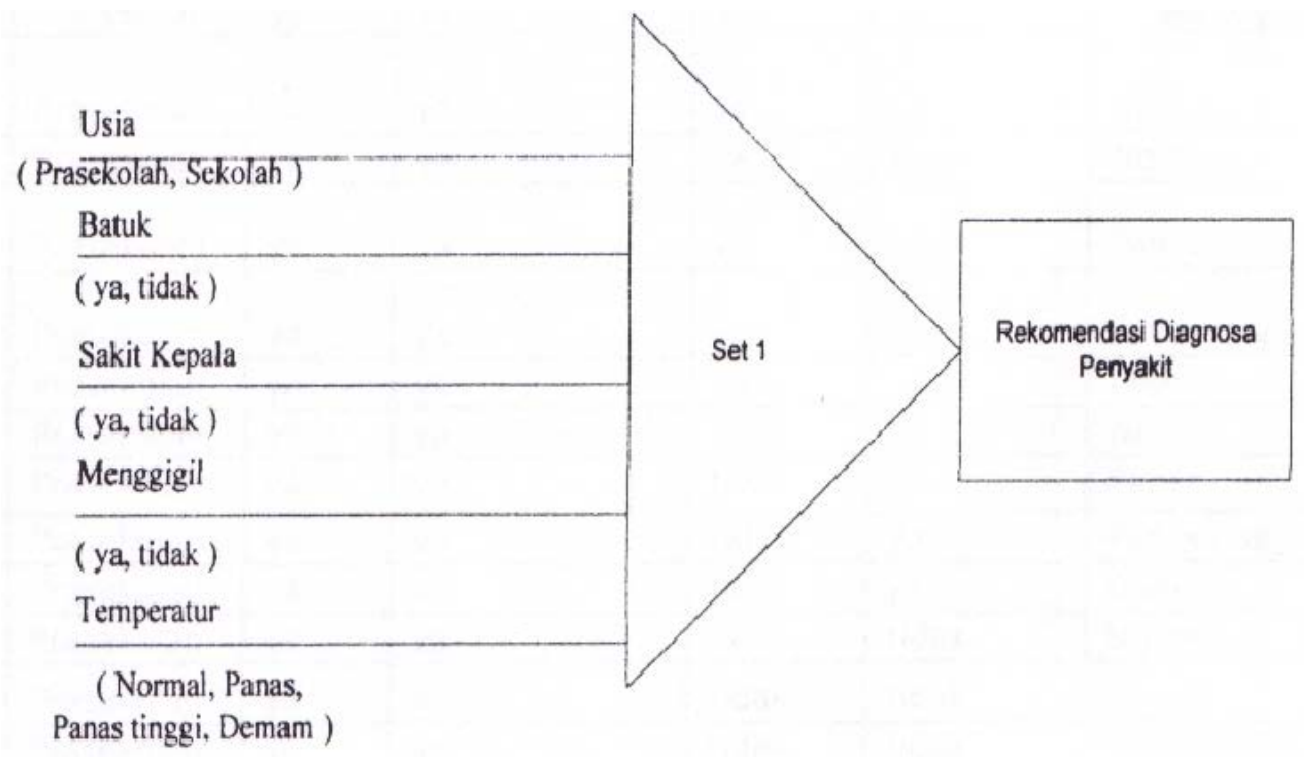

Gambar Arsitektur Diagram Ketergantungan 


\subsection{Membentuk Tabel-Tabel Pengambilan Keputusan}

Tabel-tabel pengambilan keputusan (decision tables) diperlukan untuk menunjukkan hubungan antara nilai-nilai yang keluar dan masuk dari atau ke fase-fase bagian tengah atau rekomendasi akhir sistem pakar.

Tabel Pengambilan Keputusan untuk Rule Set 1

\begin{tabular}{|c|c|c|c|c|c|c|c|}
\hline No & Usia & Batuk & $\begin{array}{l}\text { Mual / } \\
\text { Muntah }\end{array}$ & $\begin{array}{c}\text { Sakit } \\
\text { Kepala }\end{array}$ & Mengigil & Temperatur & Penyakit \\
\hline 1 & Prasekolah & ya & ya & ya & ya & Normal & $x$ \\
\hline 2 & Prasekolah & ya & ya & ya & ya & Panas & $x$ \\
\hline 3 & Prasekolah & ya & ya & ya & ya & Panas tinggi & $x$ \\
\hline 4 & Prasekolah & ya & ya & ya & ya & Demam & $\begin{array}{c}\text { Infeksi Virus } \\
\text { Influenza }\end{array}$ \\
\hline 5 & Prasekolah & ya & ya & ya & tidak & Normal & $x$ \\
\hline 6 & Prasekolah & ya & ya & ya & tidak & Panas & $x$ \\
\hline 7 & Prasekolah & ya & ya & ya & tidak & Panas tinggi & \\
\hline 8 & Prasekolah & ya & ya & ya & tidak & Demam & $x$ \\
\hline 9 & Prasekolah & ya & ya & tidak & ya & Normal & $x$ \\
\hline 10 & Prasekolah & ya & ya & tidak & ya & Panas & $x$ \\
\hline 11 & Prasekolah & ya & ya & tidak & ya & Panas tinggi & $x$ \\
\hline 12 & Prasekolah & ya & ya & tidak & ya & Demam & $x$ \\
\hline 13 & Prasekolah & ya & ya & tidak & tidak & Normal & \\
\hline 14 & Prasekolah & ya & ya & tidak & tidak & Panas & $x$ \\
\hline 15 & Prasekolah & ya & ya & tidak & tidak & Panas tinggi & $x$ \\
\hline 16 & Prasekolah & ya & ya & tidak & tidak & Demam & $x$ \\
\hline 17 & Prasekolah & ya & tidak & ya & ya & Normal & $x$ \\
\hline 18 & Prasekolah & ya & tidak & ya & ya & Panas & $x$ \\
\hline 19 & Prasekolah & ya & tidak & ya & ya & Panas tinggi & $x$ \\
\hline 20 & Prasekolah & ya & tidak & ya & ya & Demam & $x$ \\
\hline 21 & Prasekolah & ya & tidak & ya & tidak & Normal & $x$ \\
\hline 22 & Prasekolah & ya & tidak & ya & tidak & Panas & $x$ \\
\hline 23 & Prasekolah & ya & tidak & ya & tidak & Panas tinggi & $x$ \\
\hline 24 & Prasekolah & ya & tidak & ya & tidak & Demam & $x$ \\
\hline 25 & Prasekolah & ya & tidak & tidak & ya & Normal & $x$ \\
\hline 26 & Prasekolah & ya & tidak & tidak & ya & Panas & $x$ \\
\hline 27 & Prasekolah & ya & tidak & tidak & ya & Panas tinggi & $x$ \\
\hline 28 & Prasekolah & ya & tidak & tidak & ya & Demam & Demam Q \\
\hline 29 & Prasekolah & ya & tidak & tidak & tidak & Normal & $\begin{array}{c}\text { Batuk } \\
\text { disertai } \\
\text { sesak napas } \\
\text { / radang } \\
\text { paru-paru }\end{array}$ \\
\hline 30 & Prasekolah & ya & tidak & tidak & tidak & Panas & $x$ \\
\hline 31 & Prasekolah & ya & tidak & tidak & tidak & Panas tinggi & $\begin{array}{c}\text { Antraks } \\
\text { paru - paru }\end{array}$ \\
\hline 32 & Prasekolah & ya & tidak & tidak & tidak & Demam & $\begin{array}{c}\text { Flek paru - } \\
\text { paru } \\
\text { (Tuberkulose) }\end{array}$ \\
\hline
\end{tabular}


Tabel Pengambilan Keputusan untuk Rule Set 1 (Lanjutan)

\begin{tabular}{|c|c|c|c|c|c|c|c|}
\hline No & Usia & Batuk & $\begin{array}{l}\text { Mual / } \\
\text { Muntah }\end{array}$ & $\begin{array}{c}\text { Sakit } \\
\text { Kepala }\end{array}$ & Mengigil & Temperatur & Penyakit \\
\hline 33 & Prasekolah & tidak & ya & ya & ya & Normal & $x$ \\
\hline 34 & Prasekolah & tidak & ya & ya & ya & Panas & $x$ \\
\hline 35 & Prasekolah & tidak & ya & ya & ya & Panas tinggi & Typhus (Tifoid) \\
\hline 36 & Prasekolah & tidak & ya & ya & ya & Demam & $\mathrm{x}$ \\
\hline 37 & Prasekolah & tidak & ya & ya & tidak & Normal & $x$ \\
\hline 38 & Prasekolah & tidak & ya & ya & tiaak & Panas & $x$ \\
\hline 39 & Prasekolah & tidak & ya & ya & tidak & Panas tinggi & $x$ \\
\hline 40 & Prasekolah & tidak & ya & ya & tidak & Demam & Malaria \\
\hline 41 & Prasekolah & tidak & ya & tidak & ya & Normal & $\mathrm{x}$ \\
\hline 42 & Prasekolah & tidak & ya & tidak & ya & Panas & $x$ \\
\hline 43 & Prasekolah & tidak & ya & tidak & ya & Panas tinggi & $x$ \\
\hline 45 & Prasekolah & tidak & ya & tidak & tidak & Normal & Muntah \\
\hline 46 & Prasekolah & tidak & ya & tidak & tidak & Panas & $x$ \\
\hline 47 & Prasekolah & tidak & ya & tidak & tidak & Panas tinggi & $\begin{array}{l}\text { Demam } \\
\text { berdarah }\end{array}$ \\
\hline 48 & Prasekolah & tidak & ya & tidak & tidak & Demam & $\begin{array}{l}\text { Hepatitis B } \\
\text { / Diare }\end{array}$ \\
\hline 49 & Prasekolah & tidak & tidak & ya & ya & Normal & $x$ \\
\hline 50 & Prasekolah & tidak & tidak & ya & ya & Panas & $x$ \\
\hline 51 & Prasekolah & tidak & tidak & ya & $\mathrm{La}$ & Panas tinggi & $x$ \\
\hline 52 & Prasekolah & tidak & tidak & ya & ya & Demam & $x$ \\
\hline 53 & Prasekolah & tidak & tidak & ya & tidak & Normal & $x$ \\
\hline 54 & Prasekolah & tidak & tidak & ya & cidak & Panas & $x$ \\
\hline 55 & Prasekolah & tidak & tidak & ya & tidak & Panas tinggi & $x$ \\
\hline 56 & Prasekolah & tidak & tidak & ya & tidak & Deman & $\begin{array}{c}\text { Radang } \\
\text { selaput otak } \\
\text { / Demam }\end{array}$ \\
\hline 57 & Prasekolah & tidak & tidak & tidak & ya & Normal & $x$ \\
\hline 58 & Prasekolah & tidak & tidak & Tidak & ya & Panas & $x$ \\
\hline 59 & Prasekolah & tidak & tidak & tidak & ya & Panas tinggi & $x$ \\
\hline 60 & Prasekolah & tidak & tidak & tidak & ya & Demam & $\begin{array}{r}\text { Campak } \\
\text { (Measle) }\end{array}$ \\
\hline 61 & Prasekolah & tidak & tidak & tidak & tidak & Normal & $x$ \\
\hline 62 & Prasekolah & tidak & tidak & tidak & tidak & Panas & $\begin{array}{c}\text { Cacar air / } \\
\text { Panas } \\
\end{array}$ \\
\hline 63 & Prasekolah & tidak & tidak & tidak & tidak & Panas tinggi & $\begin{array}{l}\text { Infeksi saluran } \\
\text { kemih }\end{array}$ \\
\hline 64 & Prasekolah & tidak & tidak & tidak & tidak & Demam & Infeksi telinga \\
\hline 65 & Sekolah & ya & ya & ya & ya & Normal & $x$ \\
\hline 66 & Sekolah & ya & ya & ya & ya & Panas & $x$ \\
\hline 67 & Sekolah & ya & ya & ya & ya & Panas tinggi & $x$ \\
\hline 68 & Sekolah & ya & ya & ya & ya & Demam & $x$ \\
\hline 69 & Sekolah & ya & ya & ya & tidak & Normal & $x$ \\
\hline 70 & Sekolah & ya & ya & ya & tidak & Panas & $x$ \\
\hline 71 & Sekolah & ya & ya & ya & tidak & Panas tinggi & $x$ \\
\hline 72 & Sekolah & ya & ya & ya & tidak & Demam & $x$ \\
\hline
\end{tabular}


Tabel Pengambilan Keputusan untuk Rule Set 1 (Lanjutan)

\begin{tabular}{|c|c|c|c|c|c|c|c|}
\hline No & Usia & Batuk & $\begin{array}{l}\text { Mual / } \\
\text { Muntah }\end{array}$ & $\begin{array}{c}\text { Sakit } \\
\text { Kepala }\end{array}$ & Mengigil & Temperatur & Penyakit \\
\hline 73 & Sekolah & ya & ya & tidak & ya & Normal & $x$ \\
\hline 75 & Sekolah & ya & ya & tidak & ya & Panas tinggi & $x$ \\
\hline 76 & Sekolah & ya & ya & tidak & ya & Demam & $x$ \\
\hline 77 & Sekolah & ya & ya & tidak & tidak & Normal & $x$ \\
\hline 78 & Sekolah & ya & ya & tidak & tidak & Panas & $x$ \\
\hline 79 & Sekolah & ya & ya & tidak & tidak & Panas tinggi & $x$ \\
\hline 80 & Sekolah & ya & ya & tidak & tidak & Demam & $x$ \\
\hline 81 & Sekolah & ya & tidak & ya & ya & Normal & $x$ \\
\hline 82 & Sekolah & ya & tidak & ya & ya & Panas & $x$ \\
\hline 83 & Sekolah & ya & tidak & ya & ya & Panas tinggi & $x$ \\
\hline 84 & Sekolah & ya & tidak & ya & ya & Demam & $x$ \\
\hline 85 & Sekolah & ya & tidak & ya & tidak & Normal & $x$ \\
\hline 86 & Sekolah & ya & tidak & ya & tidak & Panas & $x$ \\
\hline 87 & Sekolah & ya & tidak & ya & tidak & Panas tinggi & $x$ \\
\hline 88 & Sekolah & ya & tidak & ya & tidak & Demam & $x$ \\
\hline 89 & Sekolah & ya & tidak & tidak & ya & Normal & $x$ \\
\hline 90 & Sekolah & ya & tidak & tidak & ya & Panas & $x$ \\
\hline 91 & Sekolah & ya & tidak & tidak & ya & Panas tinggi & $x$ \\
\hline 92 & Sekolah & ya & tidak & tidak & ya & Demam & $x$ \\
\hline 93 & Sekolah & ya & tidak & tidak & tidak & Normal & $x$ \\
\hline 94 & Sekolah & ya & tidak & tidak & tidak & Panas & $x$ \\
\hline 95 & Sekolah & ya & tidak & tidak & tidak & Panas tinggi & $x$ \\
\hline 96 & Sekolah & ya & tidak & tidak & tidak & Demam & $x$ \\
\hline 97 & Sekolah & tidak & ya & ya & ya & Normal & $x$ \\
\hline 98 & Sekolah & tidak & ya & ya & ya & Panas & $x$ \\
\hline 99 & Sekolah & tidak & ya & ya & ya & Panas tinggi & $x$ \\
\hline 100 & Sekolah & tidak & ya & ya & ya & Demam & $x$ \\
\hline 101 & Sekolah & tidak & ya & ya & tidak & Normal & $x$ \\
\hline 102 & Sekolah & tidak & ya & ya & tidak & Panas & $x$ \\
\hline 103 & Sekolah & tidak & ya & ya & tidak & Panas tinggi & $x$ \\
\hline 104 & Sekolah & tidak & ya & ya & tidak & Demam & $x$ \\
\hline 105 & Sekolah & tidak & ya & tidak & ya & Normal & $x$ \\
\hline 106 & Sekolah & tidak & ya & tidak & ya & Panas & $x$ \\
\hline 107 & Sekolah & tidak & ya & tidak & ya & Panas tinggi & $x$ \\
\hline 108 & Sekolah & tidak & ya & tidak & ya & Demam & $x$ \\
\hline 109 & Sekolah & tidak & ya & tidak & tidak & Normal & $x$ \\
\hline 111 & Sekolah & tidak & ya & tidak & tidak & Panas tinggi & $x$ \\
\hline 112 & Sekolah & tidak & ya & tidak & tidak & Demam & $x$ \\
\hline 113 & Sekolah & tidak & tidak & ya & ya & Normal & $x$ \\
\hline 114 & Sekolah & tidak & tidak & ya & ya & Panas & $x$ \\
\hline 115 & Sekolah & tidak & tidak & ya & ya & Panas tinggi & $x$ \\
\hline 116 & Sekolah & tidak & tidak & ya & ya & Demam & $x$ \\
\hline 117 & Sekolah & tidak & tidak & ya & tidak & Normal & $x$ \\
\hline 118 & Sekolah & tidak & tidak & ya & tidak & Panas & $x$ \\
\hline 119 & Sekolah & tidak & tidak & ya & tidak & Panas tinggi & $x$ \\
\hline 120 & Sekolah & tidak & tidak & ya & tidak & Domam & $x$ \\
\hline 121 & Sekolah & tidak & tidak & tidak & ya & Normal & $x$ \\
\hline 122 & Sekolah & tidak & tidak & tidak & ya & Panas & $x$ \\
\hline 123 & Sekolah & tidak & tidak & tidak & ya & Panas tinggi & $x$ \\
\hline 124 & Sekolah & tidak & tidak & tidak & ya & Demam & $x$ \\
\hline
\end{tabular}


Tabel Pengambilan Keputusan untuk Rule Set 1 (Lanjutan)

\begin{tabular}{|c|c|c|c|c|c|c|c|}
\hline No & Usia & Batuk & $\begin{array}{c}\text { Mual / } \\
\text { Muntah }\end{array}$ & $\begin{array}{c}\text { Sakit } \\
\text { Kepala }\end{array}$ & Mengigil & Temperatur & Penyakit \\
\hline 125 & Sekolah & tidak & tidak & tdak & tidak & ${ }^{6}$ Normal & $\mathrm{x}$ \\
\hline 126 & Sekolah & tidak & tidak & tidak & tidak & ${ }^{7}$ Panas & $\mathrm{x}$ \\
\hline 127 & Sekolah & tidak & tidak & tidak & tidak & ${ }^{8}$ Panas tinggi & $\mathrm{x}$ \\
\hline 128 & Sekolah & tidak & tidak & tidak & tidak & ${ }^{9}$ Demam & $\mathrm{x}$ \\
\hline
\end{tabular}

Setelah membuat tabel pengambilan keputusan untuk rule set 1 maka, akan dilakukan reduksi (penyederhanaan) dari tabel tersebut, agar pengambilan keputusan untuk rule set 1 lebih tepat.

Tabel Pengambilan Keputusan untuk Rule Set 1 yang telah Direduksi

\begin{tabular}{|c|c|c|c|c|c|c|c|}
\hline No & Usia & Batuk & $\begin{array}{l}\text { Mual / } \\
\text { Muntah }\end{array}$ & $\begin{array}{c}\text { Sakit } \\
\text { Kepala }\end{array}$ & Mengigil & Temperatur & Penyakit \\
\hline 1 & Prasekolah & ya & ya & ya & ya & Normal & $x$ \\
\hline 2 & Prasekolah & ya & ya & ya & ya & Panas & $x$ \\
\hline 3 & Prasekolah & ya & ya & ya & ya & Panas Tinggi & $x$ \\
\hline 4 & Prasekolah & ya & ya & ya & ya & Demam & $\begin{array}{c}\text { Infeksi Virus } \\
\text { Influenza }\end{array}$ \\
\hline 5 & Prasekolah & ya & ya & ya & tidak & Normal & $x$ \\
\hline 6 & Prasekolah & ya & ya & ya & tidak & Panas & $x$ \\
\hline 7 & Prasekolah & ya & ya & ya & tidak & Panas tinggi & $x$ \\
\hline 8 & Prasekolah & ya & ya & ya & tidak & Demam & $x$ \\
\hline 9 & Prasekolah & ya & ya & tidak & Don't Care & Don't Care & $x$ \\
\hline 10 & Prasekolah & ya & ya & tidak & Don't Care & Don't Care & $x$ \\
\hline 11 & Prasekolah & ya & tidak & ya & Don't Care & Don't Care & $x$ \\
\hline 12 & Prasekolah & ya & tidak & ya & Don't Care & Don't Care & $x$ \\
\hline 13 & Prasekolah & ya & tidak & tidak & ya & Normal & $x$ \\
\hline 14 & Prasekolah & ya & tidak & tidak & ya & Panas & $x$ \\
\hline 15 & Prasekolah & ya & tidak & tidak & ya & Panas tinggi & $x$ \\
\hline 16 & Prasekolah & ya & tidak & tidak & ya & Demam & Demam Q \\
\hline 17 & Prasekolah & ya & tidak & tidak & tidak & Normal & $\begin{array}{c}\text { Batuk disertai } \\
\text { sesak napas / } \\
\text { radang paru- } \\
\text { paru }\end{array}$ \\
\hline 18 & Prasekolah & ya & tidak & tidak & tidak & Panas & $x$ \\
\hline 19 & Prasekolah & ya & tidak & tidak & tidak & Panas tinggi & $\begin{array}{c}\text { Antraks paru - } \\
\text { paru }\end{array}$ \\
\hline 20 & Prasekolah & ya & tidak & tidak & tidak & Demam & $\begin{array}{c}\text { Flek paru - } \\
\text { paru } \\
\text { (Tuberkulose) }\end{array}$ \\
\hline 21 & Prasekolah & tidak & ya & ya & ya & Normal & $x$ \\
\hline 22 & Prasekolah & tidak & ya & ya & ya & Panas & $x$ \\
\hline
\end{tabular}

\footnotetext{
${ }^{6}$ Normal $=36$ sampai 37 Derajat Celcius.

${ }^{7}$ Panas $=37$ sampai 39 Derajat Celcius.

${ }^{8}$ Panas tinggi $=39$ sampai 40 (40 keatas) Derajat Celcius.

${ }^{9}$ Demam $=38$ sampai 40 Derajat Celcius.
} 
Tabel Pengambilan Keputusan untuk Rule Set 1 yang telah Direduksi

(Lanjutan)

\begin{tabular}{|c|c|c|c|c|c|c|c|}
\hline No & Usia & Batuk & $\begin{array}{l}\text { Mual / } \\
\text { Muntah }\end{array}$ & $\begin{array}{c}\text { Sakit } \\
\text { Kepala }\end{array}$ & Mengigil & Temperatur & Penyakit \\
\hline 23 & Prasekolah & tidak & ya & ya & ya & Panas tinggi & Typhus (Tifoid) \\
\hline 24 & Prasekolah & tidak & ya & ya & ya & Demam & $x$ \\
\hline 25 & Prasekolah & tidak & ya & ya & tidak & Normal & $x$ \\
\hline 26 & Prasekolah & tidak & ya & ya & tidak & Panas & $x$ \\
\hline 27 & Prasekolah & tidak & ya & ya & tidak & Panas tinggi & $x$ \\
\hline 28 & Prasekolah & tidak & ya & ya & tidak & Demam & Malaria \\
\hline 29 & Prasekolah & tidak & ya & tidak & ya & Don't Care & $x$ \\
\hline 30 & Prasekolah & tidak & ya & tidak & tidak & Normal & Muntah \\
\hline 31 & Prasekolah & tidak & ya & tidak & tidak & Panas & $\mathrm{x}$ \\
\hline 32 & Prasekolah & tidak & ya & tidak & tidak & Panas tinggi & $\begin{array}{l}\text { Demam } \\
\text { berdarah }\end{array}$ \\
\hline 33 & Prasekolah & tidak & ya & tidak & tidak & Demam & $\begin{array}{c}\text { Hepatitis B / } \\
\text { Diare }\end{array}$ \\
\hline 34 & Prasekolah & tidak & tidak & ya & ya & Don't Care & $x$ \\
\hline 35 & Prasekolah & tidak & tidak & ya & tidak & Normal & $x$ \\
\hline 36 & Prasekolah & tidak & tidak & ya & tidak & Panas & $x$ \\
\hline 37 & Prasekolah & tidak & tidak & ya & tidak & Panas tinggi & $x$ \\
\hline 38 & Prasekolah & tidak & tidak & ya & tidak & Demam & \begin{tabular}{|c|} 
Radang \\
selaput otak / \\
Demam
\end{tabular} \\
\hline 39 & Prasekolah & tidak & tidak & tidak & ya & Normal & $x$ \\
\hline 40 & Prasekolah & tidak & tidak & tidak & ya & Panas & $x$ \\
\hline 41 & Prasekolah & tidak & tidak & tidak & ya & Panas tinggi & $x$ \\
\hline 42 & Prasekolah & tidak & tidak & tidak & ya & Demam & $\begin{array}{l}\text { Campak } \\
\text { (Measle) }\end{array}$ \\
\hline 43 & Prasekolah & tidak & tidak & tidak & tidak & Normal & $x$ \\
\hline 44 & Prasekolah & tidak & tidak & tidak & tidak & Panas & $\begin{array}{c}\text { Cacar air / } \\
\text { Panas }\end{array}$ \\
\hline 45 & Prasekolah & tidak & tidak & tidak & tidak & Panas tinggi & $\begin{array}{c}\text { Infeksi saluran } \\
\text { kemih }\end{array}$ \\
\hline 46 & Prasekolah & tidak & tidak & tidak & tidak & Demam & Infeksi telinga \\
\hline 47 & Sekolah & $\begin{array}{l}\text { Don't } \\
\text { Care }\end{array}$ & $\begin{array}{l}\text { Don't } \\
\text { Care }\end{array}$ & $\begin{array}{l}\text { Don't } \\
\text { Care }\end{array}$ & $\begin{array}{l}\text { Don't } \\
\text { Care }\end{array}$ & $\begin{array}{l}\text { Don't } \\
\text { Care }\end{array}$ & $x$ \\
\hline
\end{tabular}

\section{KESIMPULAN DAN SARAN}

Pada akhir dari penelitian ini, dapat ditarik beberapa kesimpulan dan saran yang dapat dilakukan dalam rangka mengembangkan hasil penelitian ini di kelak kemudian hari.

\subsection{Kesimpulan}

Setelah menganalisa spesifikasi sistem dan membuat implementasi sistem untuk mendiagnosa penyakit pada balita dalam penelitian ini, ternyata sangat rumit untuk menentukan penyakit dan pengobatannya karena semua berhubungan dengan dengan nyawa pasien, maka sistem ini bisa dibuat program kepakarannya tapi kepakaran dalam sistem ini belum bisa menyamai atau menggantikan dokter. Dalam membuat program kepakaran untuk sistern dalam penelitian ini sebenarnya tidak terlalu sulit karena data nenyakit untuk kepakaran tidak terlalu banyak dan kepakarannya belum akurat dalam menyamai atau menggantikan seorang dokter. 


\subsection{Saran}

Pada penelitian perancangan sistem pakar dalam mendiagnosa penyakit pada balita ini masih jauh dan belum sempurna dan masih banyak yang harus dibenahi antara lain block diagram dan dependency diagram yang masih sangat sederhana karena jumlah data penyakit balitanya masih pada penelitian ini yang diimplementasikan kedalam program rule maka kepakarannya hanya bisa mengenal beberapa penyakit yang ada pada penelitian ini dan belum bisa untuk disamakan atau menggantikan seorang dokter karena data penyakit untuk kepakarannya masih sedikit dan perlu ditambahi lagi untuk bisa lebih mendekati kepakaran seorang dokter atau dapat menggantikan seorang dokter.

\section{DAFTAR PUSTAKA}

A.J. Gonzales and D.D. Dankel, The Engineering of Knowledge-Based System : Theory and Practice/Book. 1993.

Dologite, D, G., Developing Knowledge-Based Systems Using VP-Expert, City university of New York Bernard M. Baruch College.

Giarattano, j. \& Riey, G., Expert System Principles and programming, PWS Publishing Company, Boston. 1994.

Irfan inteligensia_mesin.pdf

Richard, E. \& Victor C., Ilmu Kesehutan Anak, Jakarta.1988.

Turban, E., Decicion Support System and Expert System, Prentice Hall International Inc., USA. 1995. 